\title{
6. Mastering Both: The Planned and the Unforeseen An Epistemological Investigation of Swedish Military Professionalism
}

\author{
Lotta Victor Tillberg
}

\section{The Swedish Armed Forces - Today and in the Future}

The primary purpose and responsibility of the Swedish Armed Forces (SAF) is formulated in its mission statement: "Swedish sovereignty, rights, interests and our fundamental values shall be protected. Our security policy aims at preserving our freedom of action and defending against political, military or any other kind of pressure" (Government Offices of Sweden, 2015). For the armed forces, this involves deterring and, in a worst-case scenario, responding to, military attacks against Sweden of all kinds. Today, these responsibilities are not limited to operations within the nation's borders since, in recent decades, international missions have formed a central part of the SAF's activities.

In line with other European countries, the SAF endorse the fact that a traditional understanding of war, with an exclusive focuses on borders and territory, is no longer solely valid; it must now include media, social and economic influences, grey zone problems and hybrid wars (Försvarsmakten, 2018). The Swedish military 
strategy doctrine describes, for example, the importance of "continually clarifying interfaces and partnerships with other actors" (Försvarsmakten, 2016, p. 36). This is to be done through cooperation: "We must be able to provide as well as receive civil and military support" (Government Offices of Sweden, 2015). The current reshaping of the Swedish Armed Forces is not about steering it back to a national territorial focus or returning to the order and organisational principles that applied before the fall of the Berlin Wall. The challenge involves building a new military defence meeting the requirement to "act on demand," both nationally and internationally (Försvarsmakten, 2017, p. 18). This reconfiguration of the SAF follows the same development documented in numerous others Western countries (Moskos, Williams \& Segal, 2000; Snider \& Matthews, 2005; King, 2011).

Some interdependent factors become particularly important in the Swedish case: Staffing levels and the ability to increase the number of employees are crucial to meet this task. The Swedish Armed Forces have gone from being one of Sweden's largest educational institutions at the beginning of the 1980s (with a national focus), to being radically downscaled during the 1990s and beginning of the 2000s (with an international focus), before once again being vigorously expanded during the 2020s. Now expansion on all fronts is required, including a more than doubling of the number of personnel, with an increase from 53,900 to 118,600 (Försvarsmakten 2018, p. 61).

In Sweden today, the concept of total defence is emphasized as the strategic order under which "the Swedish Armed Forces must work together with the rest of society to meet the challenges during times of peace, crisis, heightened state of preparedness, and war" (Försvarsmakten, 2016, p. 45). This in turn highlights the importance of the population's understanding of, and support for, strong defence of the nation: "The whole of Swedish society has a role to play in the total defence system and the public's support of the total defence system is key to the will to defend the nation and ultimately for Sweden's defence capability" (SOU, 2016, p. 50). Together these three factors - growth, total defence and public support form the arena that the SAF need to address and manage.

Another factor is that the nature of peacekeeping operations has changed since the end of the Cold War in 1991, with peace now rarely being a realistic ultimate objective. Initially presented as a "traditional" peacekeeping mission but subsequently developing into the most extensive and complex Swedish military mission in modern times, the experience of the war in Afghanistan (2004-2014) serves as an instructive example of the complexity of military missions in the 21 st century where, despite massive institutional, military and humanitarian efforts, there is no victory to be won and no peace in prospect. In retrospect, when analysing the Swedish military contribution in Afghanistan it was concluded: "The effort did 
not comply with Swedish traditional crisis management, since this was not flexible enough to provide it with an adequate management structure" (SOU, 2017, p. 12). When the Government Offices of Sweden (2017) subsequently evaluated the mission, it was determined that, while "the fulfilment of the objectives of the Swedish engagement in Afghanistan between 2002 and 2014 was highly inadequate" (Government Offices of Sweden, 2017, p. 11), "objectives were fulfilled satisfactorily in terms of Sweden's credibility and capability as a participant in international military operations" (Government Offices of Sweden 2017, p. 12). ${ }^{1}$

These factors, among others, form new conditions and place new demands on the officers' professional skills (Edström, Lunde \& Matlary, 2009; Ledberg, 2019). Concepts such as "comprehensive approach," "end state" and "second generation peacekeeping" indicate that military engagement requires not only military units but collaboration with a range of civilian specialists, too, if societal change and the building of civilian institutions are to be possible (Granberg, 2013, p. 23). Today, participation in international operations is considered just as important as the building of national defence. Consequently, the SAF and its employees are expected to be able to collaborate with a diverse range of actors in various complex interfaces, both nationally and internationally. This is the context shaping the officer's experience of service today. If what it means to be a skilled officer today is no longer what it meant during the post-Cold War period, we need new ways of understanding and developing military professionalism.

\section{Aim}

This chapter investigates how these new objectives and the organisational conditions they imply together re-shape what it means to be an officer in the Swedish Armed Forces. An investigation of professionalism as a concept must include both an organisational perspective (in the form of systems, methods, rules, objectives, etc.) and a focus on the people in the organisation - in this case, the officers. There are many ways of defining military professionalism (Snider \& Matthews, 2005; Paparone, Anderson \& McDaniel, 2008). This article follows the view expressed by the SAF, which is that an officer's professionalism involves acting according to "scientific data and proven experience" (Försvarsmakten, 2006, p. 16). The the-

1 See also Agrell (2013), describing Sweden's involvement in the Afghanistan mission as sort of sliding into "a war that just happened" that "the interventions were meant to stabilise and normalise." This was not what happened, however; rather, "the interventions brought about armed conflicts" and "stabilisation led to chaos" (p. 318) 
oretical starting point is the epistemology of professional knowledge, sometimes also referred to as - or closely related to - the epistemology of reflective practice, and follows the distinction made by the philosopher Gilbert Ryle (1949, pp. 25-51) between practical knowledge (knowing how) and propositional knowledge (knowing that). By using a set of epistemological concepts, this chapter presents an analytical framework that focuses on the types of knowledge an officer needs in order to act professionally and to meet the various demands made upon them.

Founded on the assumption of skills being knowledge expressed in action, with a focus on the active sense of knowing rather than on knowledge as a passive noun (Ryle, 1949; Schön, 1983; Snider, 2017), this investigation further aims to explore and problematize the concept of "military professionalism" in Swedish military practice. By illuminating the ongoing transformation of the SAF with the help of epistemological perspectives, the focus is broadened to not only describe the goal - that is, what is to be achieved - but to describe the skills required and the learning processes supporting them. Two theoretical lenses are borrowed from Ellström (1997, p. 45): the concept of competence-in-use (Figure 1) and a distinction between theoretical/explicit knowledge and experience-based/implicit know-how (Table 1).

The empirical part of the investigation builds on data (selected quotes) from two research projects conducted within the SAF. The research project Modern Military Professionalism (MMP), begun more than 10 years ago, is a longitudinal qualitative study documented in a series of anthologies (Tillberg, Svartheden \& Engstedt, 2008; Tillberg \& Tillberg, 2013; Tillberg, Tillberg, Svartheden, Rahmström \& Hildebrandet, 2017; Victor Tillberg, 2018; Victor Tillberg, 2020). MMP investigates Swedish military professional skills by allowing officers to describe experiences of situations in which their judgement has been tested and their skills demonstrated. Both in-depth interviews and a specific writing method have been used. ${ }^{2}$ While the main focus has been on situations where officers have met and handled problematic situations during international missions, the material also contains descriptions of challenging situations at home. As a more specified continuation and complement to the above investigation, five in-depth interviews with Swedish officers were conducted between 2016 and 2020. In this part of the study, more precise questions were asked about the relationship and the differences

2 The writing method used is the Dialogue Seminar Method (DSM). DSM combines systematically conducted meetings with informants' writing about their own experience of challenging situations followed by subsequently structured and documented focus group discussions (Göranzon, Hammarén \& Ennals, 2006). A thorough description of the MMP research project can be found in Uppdrag militär - perspektiv på militärt yrkeskunnande (2018). 
between the use of military skills at home and abroad. The officers interviewed were all men born between 1955 and 1970. At the time of interview, two were lieutenant colonels, one was a colonel and two were generals. Three represented the army, one the navy and one the air force. Four were actively engaged in managerial assignments at SAF headquarters and one had assignments in an international military headquarter abroad. All five had experience of international missions; four had held commanding positions in a mission of this kind. These interviews constitute the principal empirical part of the analysis of this chapter.

Following this is a brief overview of the ways in which the officer's role has developed over time, both internationally and in Sweden. The theoretical starting points are then described; here, the concept of competence-in-use serves as a basis for an in-depth discussion of how different perspectives on knowledge have consequences for the perception of professionalism in the profession of officer. In the reflection that follows, theoretical perspectives are interspersed with the officers' statements and with other sources. In the concluding discussion, suggestions are made for alternative ways of rethinking and understanding the paradoxes and contradictions integral to the concept of modern military professionalism. Given the limited nature of the empirical data, the purpose of the chapter is not to present any general conclusions; the interviewees' statements and other examples are used exploratively, generating and describing deeper insight into different perspectives, thereby contributing to the ongoing dynamic discussion concerning what military professionalism is - or what it should be.

\section{The Officer and Military Professionalism}

According to the policy document "Vår militära profession - agerar när det krävs" ("Our military profession - action when action is required") (Försvarsmakten, 2017, p. 25), the Swedish Officer's distinctive area of expertise is the ability to lead and organise armed combat and to "decide when, and to what degree, military force must should be used to carry out the task." The document continues:

Various areas of knowledge interact and integrate in a professional expertise that embraces theoretical, practical and experience based knowledge. The officer's role is to coordinate these combined capabilities to achieve the desired effect. This requires a complex system for the division of labour within the organization, which is divided according to both horizontally and vertically in terms of competence requirements. (Försvarsmakten, 2017) 
The Swedish officer must therefore be able to act in constantly changing environments and to collaborate both horizontally and vertically - that is, both within their own organisation and with representatives of other organisations. The transition from a mass army to smaller defence-oriented units gives the term "military professionalism" new meaning. In 1975, Feld defined military professionalism as "an officer class conforming to a model according to which the recruitment, training and assignment of its members are carried out entirely in terms of internally formulated criteria" (Feld, 1975, p. 192). It was important to create a system that eliminated the sense of any privileged class. Ten years later, Gates showed how the army and its officers could no longer be considered sealed from outside influences, calling it a "role expansion" where "the clear distinction between roles that existed earlier began to break down; military officers became increasingly involved in politics, statecraft, and the provision of internal as well as external defense" (Gates 1985, pp. 427-428). Paparone, Anderson \& McDaniel (2008, p. 434) discussed the possible result of this "role expansion" in terms of "setting organisational conditions that move authority to organisational members as a function of shared knowledge, competence and ethical reasoning rather than as a function of hierarchical position."

The tension between the task of using force and administrative logic is reflected in the different ways that the term "military professionalism" has been understood over time (Snider \& Matthews, 2005; Sookermany, 2012). The discussion about military professionalism thus takes place in an interchange between political, organisational, professional and individual perspectives. The SAF policy document "Vår militära profession - agerar när det krävs" ("Our military profession - action when action is required") describes desirable military skills as twofold: on one hand they should follow a military logic, founded on the essence of war; on the other, they use an administrative logic, founded on the principles of the central government (Försvarsmakten, 2017, p. 12). The SAF clearly state that to assume the profession of officer, one must master both the military logic and the logic of public administration; the two belong together, and it is not enough to know one without the other (Försvarsmakten, 2017, p. 28). In the early 2020s, discussions about the profession of officer are often about adequacy in the role and dealing with conflicting demands: "For the past two decades, professional debates have brought attention to a myriad of unconventional challenges and demands being placed upon commanders at all levels" (Roennfeldt, 2019, p. 45). ${ }^{3}$ Swedish

3 "U.S. military doctrines and policy documents list a host of relevant skill sets for officers, such as the ability to cooperate with civilians in multiagency and multinational operations abroad ... the ability to operate beyond the physical battleground and across multiple domains, including public perception $\ldots$ and the ability to think critically and creatively." Roennfeldt (2019, pp. 45-46) 
military doctrine and policy are no exception. This statement can be contrasted with Janowitz's notion that "human beings cannot operate effectively if they find themselves under the pressures of conflicting authority" (Janowitz, 1971, p. 423). But as we shall see, conflicting authority can today be said to be a basic prerequisite in military practice, a point which recent research on the officer profession has also shown (Moskos, Williams \& Segal 2000; Hasselbladh \& Ydén 2019).

\section{Competence-in-use}

Understanding that the transformation of the SAF and the impact of the previously described ongoing changes - role-expansion, the ability to master both administrative logic and military logic, and new forms of vertical and horizontal co-operation - calls for new explanatory models, which competencies are desirable and which learning processes support them? Ellström's 1997 article "The Many Meanings of Occupational Competence And Qualification” offers a theoretical model for structuring the concept of competence that has been used to order the way in which the different aspects of military professionalism can be described. The model initially distinguishes five different aspects:

1. Formal competence (measurable through, for example, years spent in school, points, grades);

2. Actual competence (the individual's potential capacity to handle problems and tasks);

3. Officially demanded competence (precise job description); and

4. Competence required by the job (the qualifications required).

Here, the first two focus on the individual's ability; the latter two focus on the external organisational aspects required by the job. Together, these form aspect 5, the actual competence-in-use, which denotes the kind of real-life situations and tasks that an individual has to perform and, thus, focuses on the interaction between the individual and the job (Ellström, 1997, pp. 42-43). 


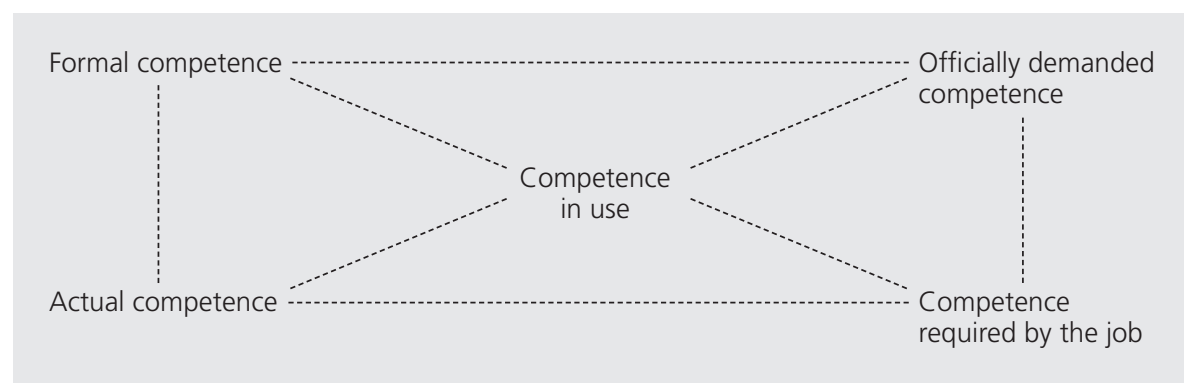

Figure 1. Different meanings of occupational competence.

The concept "competence-in-use," used as a point of departure for investigating how officers describe work-related challenges related to role- and task-expansion, directs attention to what it really means to participate actively in a professional practices. While the model was initially developed to highlight various forms of learning in an individual's professional life, it has also been used as a basic model in Swedish military education (Försvarsmakten, 1998; Försvarsmakten, 2001; Försvarsmakten, 2006). Granberg (2013), for example, understands "competence" as arising from the interaction between our subjective understanding, knowledge, skills and experiences, and different kinds of artefacts that enable certain actions, in the course of the successful execution of a specific task. Thus, competence is not only about what people "can do" individually or together; it is about what they have access to in the form of both physical resources, tools and instruments and instructions, methodology and rules.

This analysis and categorisation can serve as a starting point for the exploration of the skills and learning processes permitting and supporting the development of military professionalism, conducted through an exploration of the empirical data, that follows. What are the perceptions and experiences shared by Swedish officers of the SAF's assumption that they should master both a military and an administrative logic? The analysis shows that there is an intra-professional tension between two different positions, or topoi.

The Aristotelian concept of topos is a spatial metaphor for knowledge where one imagines that arguments, concepts and ideas are organised in relation to each other like a landscape (Wolrath Söderberg, 2019). A topos focuses on preconceived understandings and unspoken/unconscious points of departure that we consider valid and obvious and which can help draw attention to habitual argumentation and reasoning. By paying attention to the arguments and the linguistic choices made, thinking becomes visible; if, as Wolrath Söderberg (2019, p. 166) describes, we are in possession of a vocabulary for these arguments and 
instances of habitual reasoning, they can be discerned, discussed, criticised and then replaced (see also Ramirez, 1995). Immediately below, the statements of two officers in the study, "Officer S" and "Officer H," are used to represent two different, yet common, lines of argument.

\section{Manoeuvre Warrior - Not an Administrator}

A Swedish officer is expected to be able to maintain combat capability whilst simultaneously operating in a public administrative structure (Försvarsmakten, 2017, p. 28). Such an expectation can be classified under what Ellström (1997) calls competence-required-by-job (Figure 1). The expectation to master both, however, is not unproblematic and is widely discussed within the profession of the Swedish officer. When Officer S notes that "if the major part of the management training concentrates on compliance with rules and repeatable anticipated actions, there is a great risk that commanders will not be capable of acting in unforeseen situations," it is out of concern that an officer's training does not foster the abilities required to handle unforeseen situations.

In Sweden, the philosophy of mission command (auftragstaktik) has been applied since the days of the Cold War. ${ }^{4}$ Generations of Swedish soldiers, including those interviewed in this study, have been schooled in an active tradition the Swedish Army Field Manual Taktik AR2 describes as being "practised both through the commander assigning tasks, issuing guidelines and allocating resources, and by allowing the person solving the task to decide as much as possible about how it will be achieved (Försvarsmakten, 1995, p. 76); indeed, the subordinate's freedom to choose how to perform the task will only be restricted in exceptional cases (Försvarsmakten, 1995, p. 78). The Swedish officer is, therefore, schooled in an organisational system where the individual has room for flexibility and is expected to act independently and proactively.

Officer $\mathrm{S}$ continues:

Manoeuvre warfare is about staying mentally active, outsmarting the opponent, throwing him off balance and finally outmanoeuvring him. For this to be feasible, it is not people who are trained in Taylorist methodology who are required. Manoeuvre warriors are often perceived as chaotic and contentious. Such people can be perceived by

4 For a current and in-depth discussion on the application of mission command in the Swedish Armed Forces, see Palmqvist (2020). 
many as difficult to control. They do not fit into the world of management, where the primary concern is that everything is well ordered. In the bureaucracy of peace, these people do not fit in, but they are required in crises and in armed warfare. (interview with officer $\mathrm{S}$ )

Officer $\mathrm{S}$ describes how the officer's competencies do not develop within the administrative logic that the officer is expected to master in the SAF. ${ }^{5}$ The above quotes highlight the contradiction described by Ydén (2008, p. 231) as two different logics "reproduced in isolation from each other." ${ }^{\text {"T }}$ The statements by Officer $\mathrm{S}$ can be said to represent a widespread concern among his colleagues that, if they are not given the opportunity to develop and train the competence required for crisis, war and conflict situations, there is a risk that such competencies will not be developed and thus cannot be drawn on when needed. Officer $\mathrm{S}$ expresses an "either or perspective": a manoeuvre warrior is not an administrator.

\section{Combat capability and administrative skills?}

An opposing viewpoint is given by Officer $\mathrm{H}$, a high-ranking officer at the SAF headquarters:

You have to be able to manage both administration and military logic and understand the difference. For me, it is important to understand the distinction between when you can apply mission command and when you may need to be a little more guided. It depends on what the situation is and the type of task at hand. (interview with officer $\mathrm{H}$ )

Indeed, for Officer $\mathrm{H}$, both administration and warfare are necessary parts of the officer's profession that can and should be developed:

As a manager in this position, I have a number of limitations in what I can do in terms of mission command - but I also have opportuni-

5 When saying this, Officer $\mathrm{S}$ is a top-level officer with experiences at the operational, tactical and strategic levels, and has worked at headquarters both nationally and internationally.

6 The 2008 thesis "Kriget" och karriärsystemet - försvarsmaktens organiserande i fred ("The war" and the career system) uses contradictory logics of action as set out by Boënes to describe the situation in the Swedish Armed Forces. On the one hand, the logic of external conflict refers to the use of violence in life-threatening situations, contrasting with the logic of internal cooperation, which refers to interactions aimed at creating relationships and legitimacy (Ydén 2008, p. 257). 
ties. But it's something completely different from being a force commander in operation [anonymised], with different resources. There I don't have to take into account aspects that I have to consider in my current position. You must be able to separate, analyse and understand. (interview with officer $\mathrm{H}$ )

Where Officer $\mathrm{S}$ believes that it is difficult, maybe impossible, to simultaneously cultivate the competencies required to manage administrative logic and manoeuvre warfare, Officer $\mathrm{H}$ considers management and problem-solving to occur within two different knowledge domains imposing different demands: the officer must be able to "separate, analyse and understand." Thus an officer cannot choose to be either warrior and administrator; the twin capacities are a fundamental necessity. For Officer $\mathrm{H}$, it is possible to be a "warrior-administrator." Officer S's and Officer H's statements can be said to represent two different perspectives of the view of officers' competence-in-use, differentiated in the question of the taking of action in anticipated or unforeseen situations. While Officer H's endorsement of the importance of predictability, planning and control recall what is found in, and characterise, regulations, doctrine and user manuals (Försvarsmakten, 2006; Försvarsmakten, 2016; Palmqvist, 2020), the two officers' different perspectives address the question of how different kinds of knowledge produce different results.

\section{Different Aspects of Competence and Work}

Ellström (1997) offers a conceptual division between two perspectives useful in clarifying the distinctions, or contradictions, between Officer S and Officer H's statements. These are called cognitive-rational (CR) and intuitive-contextual (IC). 


\begin{tabular}{|c|c|c|}
\hline \multirow[b]{2}{*}{ Aspect } & \multicolumn{2}{|c|}{ Perspective } \\
\hline & Cognitive-rational & Intuitive-contextual \\
\hline $\begin{array}{l}\text { Type of task situation } \\
\text { Information for action }\end{array}$ & $\begin{array}{l}\text { Well defined/linear } \\
\text { Certain } \\
\text { Objective data } \\
\text { (quantitative, measurable) } \\
\text { Emotionally neutral }\end{array}$ & $\begin{array}{l}\text { Ill-defined/complex } \\
\text { Uncertain } \\
\text { Holistic sensory deprivation } \\
\text { Pattern recognition } \\
\text { Emotionally coloured }\end{array}$ \\
\hline Information processing & Analytical & Intuitive \\
\hline Mode of action & $\begin{array}{l}\text { Technical-instrumental } \\
\text { Separation between } \\
\text { planning and action } \\
\text { "Problem-solving-in-thought" }\end{array}$ & $\begin{array}{l}\text { Interactive-contextual } \\
\text { Interaction between } \\
\text { planning and action } \\
\text { "Problem-solving-in-action" }\end{array}$ \\
\hline Knowledge base & $\begin{array}{l}\text { Theoretical/declarative } \\
\text { Explicit }\end{array}$ & $\begin{array}{l}\text { Practical/experience based } \\
\text { Implicit (tacit) }\end{array}$ \\
\hline $\begin{array}{l}\text { Communication/ } \\
\text { social interaction } \\
\text { Mode of learning }\end{array}$ & $\begin{array}{l}\text { Instrumental } \\
\text { Impersonal } \\
\text { Formal education } \\
\text { and training } \\
\text { Instruction }\end{array}$ & $\begin{array}{l}\text { Dialogical } \\
\text { Personal } \\
\text { Informal learning in } \\
\text { everyday practice } \\
\text { Situated learning }\end{array}$ \\
\hline
\end{tabular}

Table 1. Some different aspects of a cognitive-rational and an intuitive-contextual perspective on cometence and work.

Here, the designation "intuitive-contextual" fits well with officers' descriptions of what is required in international operations (Tillberg, Svartheden \& Engstedt, 2008; King, 2011; Ben-Ari, 2018). Officer S, who has experience of several international engagements in commanding positions, says:

In war and crisis situations it is important to quickly create an adequate structure based on a given situation and then, from this uncertain structure, make decisions about the measures that need to be taken. It is about being able to act and take the initiative in a given situation. People who can act in uncertain situations possess one or more of the following abilities: an understanding of patterns based on experience gained from similar situations; creativity and imagination (and by this, I mean that they can quickly envisage different scenarios about what could happen if they do not act); and decisiveness. (interview with officer $\mathrm{S}$ ) 
With a clear focus on dealing with "the unforeseen," the intuitive--contextual perspective lies close to the mission command idea of solving problems and managing situations; the cognitive--rational perspective, meanwhile, conforms with the requirements for predictability and control made by an administrative logic. In this perspective, the person engaged in the activity needs to be, as expressed by Officer H, "more guided" and to accept predetermined methods for solving problems. The point made by Ellström (1997) about the division of perspectives is not that they are mutually exclusive, but, rather, that they complement each other: "In practice this means a continuous movement between routine and non-routine work, as well as well-defined, repeated tasks and poorly understood, rarely occurring problem situations" (Ellström, 1997, p. 46).

In a military context Ben-Ari (2018) frames the modern military leader's challenge as effecting "collective and coordinated action among varied constituent elements each with its own goal, interests and modes of action." The notion of "continuous movement" (Ellström, 1997), is not, however, entirely unproblematic in military practice, and it is possible that the division can only work as long as the workload is reasonable and the level of complexity is low. Ben-Ari (2018, p. 65) describes the change in the armed forces of the industrial democracies not as a linear but as a cumulative development "in which new mission, roles and environments are combined with prior ones. This model includes the simultaneous existence of older more conventional roles and behaviors together with (and not necessarily being replaced by) newer functions and practices." Regardless of the degree of complexity, the model offered by Ellström (1997) is useful in determining forms of knowledge applicable to situations that are incongruous, unpredictable and non-linear.

\section{When Rules Clash}

Earlier research on military professional skills shows that competence-in-use first becomes apparent when the task or situation requires an intervention (Blomgren, 2007; Tillberg, Svartheden \& Engstedt, 2008). Before a situation arises and a problem is solved or a task is managed, competence-in-use is merely hypothetical; an officer may have knowledge that has been demonstrated and tested during training, but never in situations where it really matters. This is the point of competence-in-use; the concept relates to genuine action.

An officer who acts - assesses, makes a choice, makes decisions - relates constantly, more or less unconsciously, to rules and instructions of various kinds. And it is useful to consider a perspective that Ellström (1997) does not explicitly highlight in the distinctions he draws, but which recurs in the officers' statements, relating to the different functions of rules. What happens when the available and 
explicitly expressed rules and instructions are either too detailed or do not cover all the relevant circumstances that must be taken into account? From time to time an officer needs to make contradictory decisions and to prioritise in the course of difficult-to-assess situations. Where Officer S spoke of the risks of complete compliance with the rules in problematic and unpredictable situations, Officer A, who has an administrative position at the SAF Headquarters, says:

I have given a lot of thought to this rule-following. The Swedish Armed Forces is an operational creature, but also a bureaucratic machine. Somewhere in all this the rules are a foundation stone of the organisation. This is called: "A predetermined task at a price known in advance." But that's not how it works in reality. (interview with officer A, my italics)

The above contains several interesting intellectual constructs. If the military organisation is both a bureaucratic machine and an operational creature - what does that mean for those active in it? Officer A implies that while the organisation may be founded on rules, there exists a discrepancy between those rules ("a predetermined task at a price known in advance") and his experience of how it works in practice ("that's not how it works in reality.") Officer A says that "in reality" some tasks are solved in other ways and refers to decisions and solutions made outside of the regulations. Another officer says: "You have to learn to cheat, to manage the system."

Officer A's statement problematises the idea that rules are perceived and applied in different ways. Managing tax-payers' money is a basic rule in all tax-financed activities; "a predetermined task at a price known in advance," then, belongs to the category normative rules. There are rules that specify which actions are permitted and which are not (Johannessen, 2006, p. 278) - laws, instructions and user manuals, for example. Normative rules are formed in such a way so as to be universal in order to suit a large range of circumstances (Tillberg, 2006, p. 160). But as consequence, a normative rule is always more or less abstract and can seldom capture every aspects of any individual case. Officers who have to act in a situation must relate to rules using both previous experiences and professional discretion.

It is useful to compare normative rules to constitutive rules. Differing from normative rules in being often unspoken and not explicitly formulated, constitutive rules are embedded in action and make themselves apparent through the ways in which the action is carried out, in terms of habits or customs (Göranzon, 2001; Tillberg, 2006). The distinction between normative and constitutive rules highlights the fact that the way a rule is formulated is no guarantee that it will be fol- 
lowed satisfactorily. In various situations, the officer needs to apply different forms of knowledge and to follow different rules depending on circumstances.

Below is an illustration of how theoretical/explicit knowledge and experience-based implicit know-how must be combined when rules clash; here, a Swedish officer in Afghanistan managing Operational Mentoring and Liaison Teams (OMLT), discusses how overall general rules (Standard Operating Procedures, or SOPs) were managed pragmatically during a mission using exemption cards:

This type of directive [an SOP] may have consequences if too detailed and also if the authority to revoke it is not granted. ISAF HQ had noticed this and introduced a Force Exemption Card, which entitled the holder to deviate from the SOP. These cards were available at different levels that provided various mandates for what to deviate from, for example what equipment to carry or rules about how you should be equipped when advancing in a vehicle. All my commanders had these cards. All I demanded of them was that they should always notify me if they decided to use them. This ensured that the on-site commander could decide to depart from the rules and regulations when they became obsolete. (Tillberg et al., 2017, p. 211)

This example is interesting for several reasons. First, the fact that there are exemption cards at all shows an organisational awareness of what is required of the person who has to take action and solve problems. Secondly, the introduction of exemption cards is a way of predicting and creating scope for flexibility in predictably unpredictable situations; they are in themselves a recognition of the multifaceted and complex nature of practice. Thirdly, in the example from Afghanistan, both normative and constitutive rules operate simultaneously. The officer and his subordinates move at the same time in the intuitive-contextual and cognitive-rational fields (Table 1). The example shows how a situation can be simultaneously well-defined (Swedish units may not operate in certain geographical areas) and difficult to assess (OMLT units should follow their Afghan partner units regardless of the geographical borders). The person who is to take action in the situation must consider objective data and regulations while assessing the development of events and taking into account the local conditions. The officer describing the example adds another aspect - that of authority: "The question is then, how do I ensure that the authority to make a different decision resides in the right place, with the right person, at the 
right time" (Tillberg et al., 2017, p. 211). A further demand, therefore, falls upon the officer, which is that of defining a certain room for flexibility and a mandate for decision-making. The question or dilemma of being able to place authority in the right and relevant person or level is also described in peacetime, at home, in the officers' time-management (Victor Tillberg, 2020, p. 56).

\section{Juggling Overwhelming Demands}

An officer is expected to manage situations arising simultaneously and from every quarter. A Swedish officer's work is performed in various "arenas," each making different demands and calling for different kinds of rules. Ben-Ari highlights this organisational development in terms of a loosening of external and internal boundaries within military organisations leading to less fixed structures and to temporary systems "whose elements, both people and technologies, are assembled and disassembled according to the shifting needs of specific projects" (Ben-Ari, 2018, p. 61).

Officer L describes his experience of the officer's profession: "The risk is that the proportions of management or performance of duties play too large a role. During daily work, all the different formal reporting routines can take over from the activities." When saying this, he provides examples from both missions abroad and at home. Administrative demands can be overwhelming in both peacetime bureaucracy and during missions (Roennfeldt, 2019; Wong \& Gerras, 2015). American officers describe how, for example, they did not report hostile contact with the enemy in Afghanistan so as to avoid having to make the subsequent obligatory storyboard presentation: "What's better - spending 15 minutes making this storyboard or planning my next operation?" and "It became a cut and paste gig" (Wong \& Gerras, 2015, p. 15). The report describes how a practice of shortcuts and sidesteps is established to escape what is perceived as an unnecessary administrative burden: "We found ways to beat the system" and "we gave them what they wanted" (Wong \& Gerras, 2015, p. 14).

Agrell (2013) observed a contrary tendency in the Swedish missions in Afghanistan. Analysing the final reports from the units, he noted the reports become increasingly extensive over time in both number of pages and richness of detail: "feeding the monster was the term used to describe RC North's endless appetite for reporting" (Agrell, 2013, pp. 325-326). The officers in Wong and Gerras's investigation of 2015, meanwhile, describe how the administrative burden prevented them from performing their real task - fulfilling the mission. Together, 
the complexity and the time required present the officers problems; at certain moments they find themselves obliged to make a choice in prioritising what is most important. Swedish officers often express similar experiences from international operations, but also concerning everyday administration (Victor Tillberg \& Tillberg, 2013). Searching for particular information in the SAF internal case management system "Vidar" is often described with the phrase "Finns i Vidar - finns i sjön ("go fish")." Similarly, the difficulty of finding information on the SAF intranet "Emilia" is described with the expression "I magen på Emilia" "“in Emilia's stomach.") And an officer who collects administrative tasks and stays behind at the computer until morning in order to work undisturbed and fully concentrated on tasks regarded as stealing time from the officer's primary function - maintaining the ability for armed combat through the training of soldiers - is said to "stay the night." This is a topic currently being fiercely debated in the Swedish officers corps. The head of the department of tactics at the Ground Combat School, also a lieutenant colonel, believes that the staff's characteristics are a consequence of "the culture in which you grow up and are immersed" and asks the critical question:

It nevertheless seems as if the Swedish Officer does not so much eat method for breakfast but is faithful to the method. But we maybe shouldn't be surprised when we examine the wording and the focus that is used in our user manuals, and how we educate and train. (Palmqvist, 2020)

This statement draws attention to the same fear that Officer S expresses - the risk that administrative tasks might hinder the development of the skills needed in combat situations.

\section{Discussion}

The development of the officer's profession (role-expansion, more and new tasks, increased demands, difficulty finding a balance between administration and core tasks) described in this chapter is not unique to the armed forces, having been high-

7 VIDAR - "Vi Dokumenterar och Arkiverar" ("We document and archive"] is the case management system used by the SAF introduced in 2013. It is a "modern documentation and case management system, where the administrators themselves manage record keeping and the processing of documents" www.cgi.se, downloaded 11 June, 2020. 
lighted in other areas of the public sector (Alvesson, 2013; Noordegraaf, 2016). New technology and changing external factors lead to a change in the content of the work and areas of responsibility (Hasselbladh, 2019; Christensen \& Lægreid, 2007). This development means that dependencies change both within organisations and in relation to the outside world and other actors. Noordegraaf (2016) describes the changing forms of professional work as an "attack on the professions":

The nature of control is at stake. Professional self-regulation was never pure and, increasingly, professionalism becomes dispersed and distributed instead of uniform and concentrated. Whereas public professional workers could protect themselves against the outside world, the outside world is increasingly penetrating professional domains, work and practices. (Noordegraaf, 2016, p. 786)

One recurring conclusion is that the power and control of the profession is at stake: "It is interesting to note that the traditional professions are mainly grounded in their professional skills, while the new groups [e.g. administrators, communicators, IT specialists, coordinators, and in some cases managers] mainly have their roles determined by the organisations' requirements and administrative work" (Ivarsson, Forsell \& Westerberg, 2014, p. 110). As shown above, within SAF, as in many other Western defence forces, the societal and organisational development trends entail changes for the officer profession. Demands and expectations are perceived by the officers interviewed as both extensive and contradictory. The fact that the officer profession is exposed to pressure from both within and without is in itself nothing new. Janowitz (1971, p. 424) is already calling for it when describing the ideal officer of the future as a "whole man" who is "both a modern heroic leader and a military manager."

What kind of skills must be developed as a result of these changes? This chapter took as its starting point competence-in-use (Ellström, 1997), a concept used to investigate the types of knowledge demanded and encouraged in Swedish military professional practice. One topos is described by Officer $\mathrm{S}$ with the words "the manoeuvre warrior is not an administrator." In this topos, the knowledge of waging war and delivering lethal force risks being subordinated to administrative tasks. Officer $\mathrm{H}$ shows us another topos, that of the "the warrior-administrator," a role constituted by skills understood as fundamentally essential: one does not have the choice of being either warrior or administrator. In the topos "warrior - not an administrator," operating within an administrative logic (administrative skills) is presented as a contrast to what it means to operate within the logic of war (combat capability). The officers in the examples express that they are either 
good at one thing, combat capability, or the other, administrative skills, and that these two fields of activity are most often disconnected or unrelated. The "warrior-administrator" topos could instead be said to follow the SAF policy document "Vår militära profession - agerar när det krävs" ("Our military profession - action when action is required") (Försvarsmakten, 2017) where combat skills and the logic of public administration are described as two equally important parts of the officer's work. These two different topoi draw attention to an important question about which forms of knowledge are active in the officer's professional practice and self-understanding. Thinking in terms of division is to (unconsciously) structure the world and make one concept a norm to which the other concept is subordinate (Ramirez, 1995, p. 11). In Figure 1, where cognitive-rational and intuitive-contextual perspectives are described, these concepts can easily be interpreted as being in opposition, even if this is not the intention of the author (Ellström, 1997).

Building on what has been discussed earlier in this chapter, the following concluding remarks suggest some alternative ways of looking at the development of the profession of officer. An exploration of how the cognitive-rational and intuitive-contextual forms of knowledge instead benefit and support each other offers a way forward for the development of military professionalism. There is also a need for research exploring the gap between officers' perceptions of the two identified mental landscapes, "the warrior - administrator" and "the manoeuvre warrior - not an administrator." One way to further explore this is to use a multilevel analysis to examine examples of modern military professionalism, both good and bad.

\section{Conclusions}

The officer's competence-in-use is based on both practical and theoretical forms of knowledge (Figure 1). The Swedish officer's professional practice takes place in a dynamic field of tensions where it is crucial that one possesses the ability to handle both anticipated administrative tasks and unforeseen situations. These tensions and dynamics are nothing new in themselves and have been previously documented in various forms (Janowitz, 1971; Snider \& Matthews 2005; Paparone, Anderson \& McDaniel, 2008). This chapter, however, contributes with a developed conceptual apparatus that can be used in further research on the risks and the potential benefits linked to these tensions. There are therefore good reasons to examine differences in this respect between the Scandinavian countries in more detail (see introduction, this volume).

Finally, what is "new" in a new modern military professionalism? Maybe not so much after all. The ingredients of modern military professionalism as they relate to 
professional judgment have been described in literature and theory for a long time. It is time to take a closer look at the professional practice at the level of execution and improve the forms of knowledge connected to officers' competence-in-use: the constant movement between theory and practice. This calls for a reconfiguration of the conceptual apparatus, taking into account the practice in itself - where clues to mastering both the planned and the unforeseen are to be found. 


\section{References}

Agrell, W. (2013). Ett krig här och nu: Sveriges väg till väpnad konflikt i Afghanistan [A war here and now: Sweden's path to armed conflict in Afghanistan]. Stockholm, Sweden: Atlantis.

Alvesson, M. (2013). The triumph of emptiness: Consumption, higher education, and work organization. Oxford, UK: Oxford University Press.

Ben-Ari, E. (2018). From leading combat units to leading combat formations - Modularity, loose systems, and temporariness. In L. V. Tillberg (Ed.), Uppdrag militär: perspektiv på militärt yrkeskunnande [Mission military: perspectives on military expertise] (pp. 53-70). Stockholm, Sweden: Centrum för Studier av Militär och Samhälle.

Blomgren, E. (2007). Caglavica 17 mars 2004: sex militära chefer berättar om ett upplopp i Kosovo [Caglavica March 17, 2004: Six military commanders report a riot in Kosovo]. Stockholm, Sweden: Försvarshögskolan.

Christensen, T., \& Lægreid, P., (2007). Transcending new public management: The transformation of public sector reforms. Surrey, England: Ashgate.

Edström, H., Lunde, N. T., \& Matlary, J. H. (2009). Krigerkultur i en fredsnasjon: Norsk militer profesjon i endring [Warrior culture in a nation of peace: The Norwegian military profession in change]. Oslo, Norway: Abstrakt Forlag.

Ellström, P.-E. (1997). The many meanings of occupational competence and qualification. In W.J. Nijhof \& J. N. Streumer (Eds.), Key qualifications in work and education (pp. 39-50). Dordrecht, Netherlands: Springer Netherlands.

Feld, M. (1975). Military professionalism and the mass army. Armed Forces and Society, 1(2), 191-214.

Forssell, A., \& Ivarsson Westerberg, A. (2014) Administrationssamhället [The administrative society]. Lund, Sweden: Studentlitteratur.

Försvarsmakten (1995). Arméreglemente del 2: AR taktik [Army regulations Part 2: AR tactics]. Stockholm, Sweden: the Swedish Armed Forces.

Försvarsmakten (1998). Utbildningsreglemente: Pedagogiska grunder [Educational regulations: Pedagogical foundations]. Stockholm, Sweden: Försvarsmakten.

Försvarsmakten (2006). Pedagogiska grunder [Pedagogical foundations]. Stockholm, Sweden: Försvarsmakten.

Försvarsmakten (2016). Militärstrategisk doktrin (MSD 16) [Military strategic doctrine]. Retrieved from https://www.forsvarsmakten.se/siteassets/4-om-myndigheten/dokumentfiler/doktriner/militarstrategisk-doktrin-2016-ny.pdf

Försvarsmakten (2017). Vår militära profession: agerar när det krävs. [Our military profession: action when action is required]. Stockholm: The Swedish Armed Forces.

Försvarsmakten. (2018). Tillväxt för ett starkare försvar: Slutredovisning av Försvarsmaktens perspektivstudie 20162018 [Growth for a stronger defence: Final report of the Swedish Armed Forces' perspective study 2016-2018]. Retrieved from https://www.forsvarsmakten.se/siteassets/4-om-myndigheten/dokumentfiler/perspektivplan/slutlig-redovisning-av-perspektivstudien-2016-2018. pdf

Gates, J. M. (1985). The "new" military professionalism. Armed Forces and Society, 11(3), 427-436. DOI: https://doi.org/10.1177\%2F0095327X8501100306

Government Offices of Sweden (2015). Sweden's Defence Policy - 2016 to 2020. Retrieved from http:// www.government.se/globalassets/government/dokument/forsvarsdepartementet/sweden_ defence_policy_2016_to_2020

Government Offices of Sweden (2017). Summary of the report of the inquiry on Wweden's engagement in Afghanistan 2002-2014. Retrieved from https://www.government.se/492dc9/contentassets/277667f528b541979f889a2143d7fdbb/summary-sou-2017-16.pdf

Granberg, M. (2013). Militär kompetens i polisiära uppgifter. En empirisk belysning och diskussion av en 
insats i Kosovo. Stockholm: Swedish Defence University, Department of Security, Strategy and Leadership.

Göranzon, B., Hammarén, M., \& Ennals, J. R. (2006). Dialogue, skill छ̊ tacit knowledge. Chichester: John Wiley \& Sons.

Hasselbladh, H. (2019). De problematiska professionerna [The problematic professions]. In C. Cederberg (Ed.), Yrkesmänniskan i den kapitaliserade välfärden [The professional in capitalized welfare] (pp. 243-264). Huddinge, Sweden: Södertörn högskola.

Hasselbladh, H., \& Ydén, K. (2019) Why military organizations are cautious about learning? Armed Forces and Society, 46(3), 475-494. DOI: https://doi.org/10.1177\%2F0095327X19832058

Janowitz, M. (1971.) The professional soldier: a social and political portrait. New York, NY: The Free Press.

Johannessen, K. S. (2006). Rule following, intransitive understanding and tacit knowledge: an investigation of the Wittgensteinian concept of practice as regards of tacit knowing. In: Göranzon, B., Hammarén, M., \& Ennals, J. R. (2006). Dialogue, skill \& tacit knowledge. Chichester: John Wiley \& Sons. Chichester: John Wiley and Sons Ltd.

King, A. (2011). The transformation of Europe's armed forces: From the Rhine to Afghanistan. Cambridge, UK: Cambridge University Press.

Ledberg, S. K. (2019). Officeren, staten och samhället: Ett professionsperspektiv [The officer, the state and society: A professional perspective]. Lund, Sweden: Nordic Academic Press.

Moskos, C. C., Williams, J. A., \& Segal, S. R. (2000). The postmodern military: Armed forces after the Cold War. New York, NY: Oxford University Press.

Noordegraaf, M. (2016). Reconfiguring professional work: Changing forms of professionalism in public services. Administration and Society, 48(7), 783-810. DOI: https://doi. org/10.1177\%2F0095399713509242

Palmqvist, O. (2020, June 15). Uppdragstaktik: en svensk papperstiger? [Assignment tactics: a Swedish paper tiger?] [Web log post]. Retrieved from https://kkrva.se/uppdragstaktik-en-svensk-papperstiger/

Paparone, C. R., Anderson, R. A., \& McDaniel, R. R. (2008). Where military professionalism meets complexity science. Armed Forces and Society, 34(3), 433-449. DOI: https://doi. org/10.1177/0095327X07310337

Ramirez, J. L. (1995). Om meningens nedkomst - En studie i antropologisk tropologi (Skapande mening Vol. 3). Stockholm, Sweden: Nordiska institutet för samhällsplanering.

Roennfeldt, C. F. (2019). Wider officer competence: The importance of politics and practical wisdom. Armed Forces \& Society, 45(1), 59-77. DOI: https://doi.org/10.1177/0095327X17737498

Ryle, G. (1949). The concept of mind. Chicago, IL: University of Chicago Press.

Schön, D. A. (1983), The reflective practitioner. How professionals think in action. New York, NY: Routledge.

Snider, D. M. (2017). Dissent, resignation, and the moral agency of senior military professionals. Armed Forces and Society, 43(1), 5-16. DOI: https://doi.org/10.1177\%2F0095327X16657322

Snider, D. M., \& Matthews, L. J. (2005). The future of the army profession. Boston, MA: McGraw-Hill Custom Publishing.

Sookermany, A. (2012). What is a skilful soldier? An epistemological foundation for understanding military skill acquisition in (post) modernized armed forces. Armed Forces and Society, 38(4), 582-603. DOI: https://doi.org/10.1177/0095327X11418320

SOU (2016). En robust personalförsörjning av det militära försvaret (2016, p. 63) [A robust supply of personnel for the military defence]. Retrieved from https://data.riksdagen.se/fil/CF7 1963C-835A45EA-8FBA-216040ECAADC

SOU (2017). Sverige i Afghanistan 2002-2014 (SOU 2017, p.16) [Sweden in Afghanistan 2002-2014]. Retrieved from https://data.riksdagen.se/fil/6B947277-972D-415A-A4A1-AA9E12B18857 


\section{References}

Tillberg, P., Svartheden, J., \& Engstedt, D. J. (2008). Mission abroad: Military experience from international operations. Stockholm, Sweden: National Defence College.

Tillberg, P., Victor Tillberg, L., Svartheden, J., Rahmström, B., \& Hildebrandt, J., (2017). Mission Afghanistan: Swedish military experiences from a 21st century war. Stockholm, Sweden: The Swedish Centre for Studies of Armed Forces and Society.

Tillberg, P. (2006) Some aspects of military practices and officers' professional skills. In: Göranzon, B., Hammarén, M., \& Ennals, J. R. (2006). Dialogue, skill \& tacit knowledge. Chichester: John Wiley \& Sons.

Victor Tillberg, L. (2020). The dynamics of military skills: The role of experience-based knowledge in challenging situations. Scandinavian fournal of Military Studies, 3(1), 55-67. DOI: http://doi. org/10.31374/sjms.40

Victor Tillberg, L. (2018). Uppdrag militär: perspektiv på militärt yrkeskunnande [Military Mission: Perspectives on militart expertise]. Stockholm, Sweden: Centrum för studier av militär och samhälle.

Victor Tillberg, L., \& Tillberg, P. (2013). Mission commander: Swedish experiences of command in the expeditionary era. Stockholm, Sweden: The Swedish Centre for Studies of Armed Forces and Society.

Wolrath Söderberg, M. (2017). Aristoteles retoriska toposlära: en verktygsrepertoar för fronesis [Aristotle's rhetorical topology: A tool repertoire for fronesis]. Huddinge, Sweden: Södertörns Högskola,

Wolrath Söderberg, M. (2019). Att göra tänkandet synligt med topisk analys [To make thinking visible with topical analysis]. In M. Gunnarson (Ed.), Att utforska praktisk kunskap: undersökande, prövande och avtäckande metoder [Exploring practical knowledge: exploratory, testing and uncovering methods] (pp. 159-193). Huddinge, Sweden: Södertörns högskola.

Wong, L., \& Gerras, S. J. (2015). Lying to ourselves: Dishonesty in the army profession. Carlisle, PA: Strategic Studies Institute \& U.S. Army War College Press.

Ydén, K. (2008). "Kriget" och karriärsystemet: försvarsmaktens organiserande i fred ["The war "and the career system: the organization of the armed forces in peace]. Gothenburg, Sweden: Bokförlaget BAS.

\section{Other sources:}

Försvarsdepartementet (December 16, 2004). Pressmeddelande, försvarsminister Leni Björklund (nedladdat www.regeringen.se 2020-06-16).

Försvarsmakten (2000). Pedagogiska grunder [Pedagogical foundations].. Stockholm, Sweden: Försvarsmakten.

Försvarsmakten (2015). Försvarsmaktens strategiska inriktning 2015 (FMSI 2015)[The Swedish Armed Forces' strategic focus 2015]. Retrieved from https://www.forsvarsmakten.se/siteassets/4-om-myndigheten/vart-uppdrag/bilaga-1-fm2025-1597-7-fmsi-2015-al.pdf 